\title{
Microbial Detoxification of Gossypol in Cotton Seed Meal by Solid Substrate Fermentation
}

\author{
Savitha Santosh ${ }^{1}$, K. P. Raghavendra ${ }^{1 *}$, K. Velmourougane ${ }^{1}$, \\ V. Mageshwaran ${ }^{2}$, D. Blaise ${ }^{1}$ and VN. Waghmare ${ }^{1}$ \\ ${ }^{1}$ ICAR - Central Institute for Cotton Research, Nagpur-440 010, Maharashtra, India \\ ${ }^{2}$ ICAR-National Bureau of Agriculturally Important Microorganisms, \\ Mau Nath Bhanjan, UP, India \\ *Corresponding author
}

\section{A B S T R A C T}

\begin{tabular}{|c|}
\hline Keywords \\
\hline $\begin{array}{l}\text { Cotton seed meal, } \\
\text { Gossypol, Solid } \\
\text { state fermentation, } \\
\text { Detoxification, } \\
\text { Laccase }\end{array}$ \\
\hline Article Info \\
\hline $\begin{array}{l}\text { Accepted: } \\
12 \text { November } 2020 \\
\text { Available Online: } \\
10 \text { December } 2020\end{array}$ \\
\hline
\end{tabular}

\begin{abstract}
Gossypol, a toxic phenolic compound present in cottonseed meal (CSM) makes it unfit for use as feed for non-ruminants. Microbial detoxification of gossypol in CSM by solid state fermentation (SSF) was known to have higher detoxification efficiency with improved nutritive value as compared to the physical and chemical methods of gossypol detoxification. This study was conducted to isolate, screen and identify efficient gossypol detoxifying microbes from the cotton rhizosphere and pink bollworm larvae. From our study, Aspergillus quadrilineatus, A. terreus, A. versicolor, Penicillium griseofulvum, Streptomyces maritimus, Streptomyces $s p$ and $S$. rochei were efficient gossypol detoxifying microorganism of CSM. Among the treatments, CSM inoculated with A. quadrilineatus, A. terreus, A. versicolor, $P$. griseofulvum showed maximum free and bound gossypol reduction in SSF. To the best of our knowledge, for the first time, we report soil isolates $P$. griseofulvum, S. maritimus, Streptomyces $s p$ and $S$. rochei as gossypol utilising microorganisms from cotton ecosystem. However, actinobacteria were not found to be as efficient as fungal isolates in reduction of free and bound gossypol.
\end{abstract}

\section{Introduction}

Cotton is an important commercial crop grown over more than 70 countries worldwide for its fibre and oil, apart from fuel and feed. Cotton plant contains a toxic compound "Gossypol", which is present in leaves, seed, stems and flower buds, and it act as a natural defense molecule against herbivorous insects and pathogens (Tian et al., 2016). Gossypol is a phenolic compound with a molecular weight of 518.5 Dalton, which is insoluble in water and hexane, but soluble in acetone, chloroform, ether and methyl ethyl ketone (Gadelha et al., 2014). Presence of gossypol in cotton seeds limits its utilization as oil and protein in non-ruminant (monogastrics) animals. Presence of gossypol in cottonseed and its by-products (cakes and meal) leads to clinical poisoning, liver damage (Blevins etal., 2010), male and female reproductive toxicity (Lin etal., 1985 and Randel etal., 
1992) and immunological impairment (Sein, 1986 and $\mathrm{Xu}$ et al., 2009). Though, gossypol present as bound and free forms (Alexander $e t$ al., 2008), free-gossypol was found to be highly reactive, binding to minerals and amino acids leading to its non availability and results in their deficiency (Braga et al., 2012). Therefore, it is highly essential to reduce the gossypol content in cottonseed meal (CSM) for its effective utilization. Several physical, chemical and biological methods have been proposed for the detoxification of gossypol in CSM. Physical techniques chiefly employ roasting, extrusion, gamma, and electron beam irradiation for gossypol detoxification (Arieli 1998, Noftsger etal., 2000 and Shawrang etal., 2011). Chemical detoxification of CSM is achieved by the addition of ferric sulfate, lysine, sodium selenite, vitamin $\mathrm{E}$ and alkali treatment, which forms complexes with free gossypol (Panigrahi and Plumb, 1996, Saki et al. 2012, EL-Mokadem et al., 2012, Velasquez-Pereira et al., 1998 and Nagalakshmi etal., 2002). However, these chemical methods are known to adversely affect the nutritive value of feed apart from having low detoxification efficiency and hence, they are not in commercial use (Sun et al., 2008). Alternatively, many microorganisms including Candida tropicalis, Torulopsis candida, Aspergillus flavus, Aspergillus niger, Pleurotus sajor-caju, Saccharomyces cerevisiae, etc. were shown to posses gossypol detoxification mechanisms (Weng and Sun, 2006, Mageshwaran and Parvez, 2016 and Mageshwaran et al., 2018). The biological approach of CSM detoxification through microbial fermentation is a very promising method for gossypol detoxification, as it is environmentally sustainable, ecofriendly, higher detoxification efficiency and also they are known to enhance the nutritive value of CSM by increasing the availability of protein, amino acids, coenzymes and vitamins $(\mathrm{Wu}$ and Chen,
1989, Brock et al., 1994, Jianyi 1997, Shi et al., 1998, Weng and Sun, 2006 and Khalaf and Meleigy, 2008). As huge quantum of cotton wastes are getting incorporated into soil each year and the pink bollworms (PBW) are known to possess gossypol detoxification mechanism, we hypotheses that cotton rhizosphere and PBW may harbour gossypol detoxifying microbes. Hence, in our present study, we attempted at isolation of native gossypol detoxifying microorganisms from cotton rhizosphere and pink boll worm and its utilization in CSM detoxification.

\section{Materials and Methods}

\section{Media preparation}

Twenty milligrams of ( \pm )-gossypol-acetic acid (Sigma Aldrich) was dissolved in two ml of dimethyl sulfoxide. One $\mathrm{ml}$ of this solution was added to $100 \mathrm{ml}$ of sterile minimal media $\left(\mathrm{NaNO}_{3}-0.5 \mathrm{~g}, \mathrm{~K}_{2} \mathrm{HPO}_{4}-0.65 \mathrm{~g}, \mathrm{KH}_{2} \mathrm{PO}_{4}-0.2 \mathrm{~g}\right.$, $\mathrm{MgSO}_{4}-0.1 \mathrm{~g}$, Agar-18g, and distilled water$1000 \mathrm{ml} \mathrm{pH}-5.5$ ) for attaining 100ppm of gossypol.

\section{Isolation of gossypol utilizing microorganisms}

To isolate gossypol detoxifying microorganisms, rhizosphere samples and PBW larvae from different cotton growing areas were collected. Dilutions $\left(10^{-5}\right)$ were prepared and spread on to minimal media with gossypol (100ppm) as a sole source of carbon and energy. To obtain isolates from the midgut of PBW larvae, the healthy larvae were starved for $4 \mathrm{~h}$ and then surface sterilized with distilled water followed by $70 \%$ ethanol. The surface sterilized larvae were transferred to petriplates containing paraffin, immobilized with sterile surgical pins, covered with sterile water, and dissected using sterile surgical blade. Only mid gut portions were collected in sterile saline 
solution, homogenized and serially diluted aseptically (Regode et al., 2016). Dilutions were spread on to minimal media with gossypol (100ppm) as sole source of carbon and energy and incubated at $30^{\circ} \mathrm{C}$. The isolates grown on the minimal media with 100 ppm gossypol were further screened with increasing concentration of gossypol on minimal media to $250 \mathrm{ppm}$ and $500 \mathrm{ppm}$ to obtain efficient gossypol detoxifying isolates. The isolates which were able to grow at higher concentrations of gossypol were selected for further studies. Stock cultures of selected isolates were maintained on agar slants at $4{ }^{\circ} \mathrm{C}$.

\section{Inoculum preparation}

The short-listed microbial isolates were grown on $100 \mathrm{ml}$ of potato dextrose broth and nutrient broth respectively at $30{ }^{\circ} \mathrm{C}$ under shaking conditions (150 rpm) for 48 hours. Four $\mathrm{ml}$ of these inoculums was used for inoculation of $20 \mathrm{~g} \mathrm{CSM}$.

\section{Solid substrate fermentation (SSF)}

The cottonseed meal (CSM) was obtained from the ICAR-CIRCOT, Regional station, Nagpur, Maharashtra. The substrate was sterilized by autoclaving at $121^{\circ} \mathrm{C}$ for $20 \mathrm{~min}$, cooled, and were inoculated with $20 \%$ of selected microbial isolates (v/w) and incubated for 72 hours at room temperature $\left(28 \pm 2^{\circ} \mathrm{C}\right)$ in triplicates. A control was maintained using sterilized media without microbial inoculation. The initial moisture content of $70 \%$ in all the treatments was maintained using sterilized distilled water.

\section{Sample processing and analyses}

After the SSF, all the samples were dried at $60^{\circ} \mathrm{C}$ for 24 hours. The processed samples were analyzed for free and total gossypol by official method of the American Oil Chemists
Society (AOCS, 1989). The bound gossypol (BG) was calculated as difference between the free gossypol (FG) and total gossypol. The percentage reduction of $\mathrm{BG}$ and $\mathrm{FG}$ in different treatments was calculated over control. The moisture content of CSM was measured by drying samples at $90^{\circ} \mathrm{C}$ till the constant weight is achieved.

\section{Screening for laccase activity}

The laccase activity of the short-listed isolates was determined qualitatively using guaiacol (0.04\%) (Kalra et al., 2013) and bromophenol blue (BPB) (0.02\%) (Tekere et al., 2001) as an indicator compound supplemented in potato dextrose agar culture plates in triplicates. All the inoculated plates were incubated at $28{ }^{\circ} \mathrm{C}$ for 3 days. In the presence of guaiacol, intense reddish brown color produced in the medium around the colonies, while in BPB assay yellow discoloration was observed. Discoloration of the dye in the culture plates indicated the presence of laccase activity and scored as positive. To screen the isolates for laccase activity levels, dye decolorisation involving BPB was carried out. Potato dextrose broth was supplemented with bromophenol-blue $(0.2 \mathrm{~g} / \mathrm{l})$, broth was inoculated with the mycelial disks $(2 \mathrm{~mm})$ and incubated at $27^{\circ} \mathrm{C}$ for 3 days along with uninoculated control. Discoloration of the dye from the broth indicated the presence of laccase (Rajesh kumar et al., 2016). The culture supernatant obtained after centrifugation (6000 rpm for $10 \mathrm{~min}$ ) was read through spectrophotometer at $660 \mathrm{~nm}$. The dye decolorisation percentage was calculated by comparing with control.

\section{Identification of Microbes using 16SrDNA and ITS sequencing}

The genomic DNA of bacterial isolates and fungal isolates were extracted using HiPurA $^{\text {TM }}$ Bacterial Genomic DNA 
Purification Kit (HiMedia, India) and DNeasy PowerLyzer Microbial kit (Qiagen, Germany) respectively, as per the manufacturer's protocol. Universal 16S rDNA primers, 27F (5'-AGAGTTTGATCCTGGCTCAG-3') and 1492R (5'- CGGTTACCTTGTTACGACTT3') (Weisburg et al., 1990) and ITS primers, ITS1 (5'-TCCGTAGGTGAACCTGCGG-3') and ITS 4 (5'-TCCTCCGCTTATT GATATGC-3') (White et al., 1990) were used for bacterial and fungal strains identification, respectively. The $20 \mu \mathrm{l}$ volume of the PCR mixture was used consisting of $2.0 \mu \mathrm{l}$ of $10 \mathrm{X}$ Taq polymerase buffer, $1.6 \mu \mathrm{l}$ of $25 \mathrm{mM}$ $\mathrm{MgCl} 2,0.4 \mu \mathrm{l}$ of $10 \mathrm{mM}$ dNTP's, $0.4 \mu \mathrm{l}$ of 10 $\mu \mathrm{M}$ each of forward and reverse primer, $0.4 \mu \mathrm{l}$ of Taq polymerase, $13.3 \mu \mathrm{l}$ of $\mathrm{ddH} 2 \mathrm{O}$, with $1.5 \mu \mathrm{l}$ DNA template of a sample. The PCR conditions for amplification were as follows; initial denaturation at $94^{\circ} \mathrm{C}$ for $4 \mathrm{~min}$, followed by 35 cycles of denaturation at $94^{\circ} \mathrm{C}$ for $45 \mathrm{~s}$, annealing at $56^{\circ} \mathrm{C}$ for $1 \mathrm{~min}$ and extension at $72^{\circ} \mathrm{C}$ for $1 \mathrm{~min} 20 \mathrm{~s}$, with a final extension at $72^{\circ} \mathrm{C}$ for $7 \mathrm{~min}$. The amplified ITS and 16SrDNA products were purified using QIAquick PCR Purification Kit as per manufacturer's instructions and sequenced from Eurofins Genomics India Pvt Ltd., Bengaluru, India. The sequences were analysed and contigs were obtined using Bio edit v7.1.9. Bioinformatics algorithm basic local alignment search tool (https://blast. ncbi.nlm.nih.gov/Blast.cgi) (Altschul et al., 1990) was used to identify and confirm the regions of the respective sequence based on their maximum per cent identity with the known sequences available at National Centre for Biotechnology Information (NCBI) GenBank nucleotide database.

\section{Statistical analyses}

All the experimental data were subjected to one way analysis of variance (ANOVA) (WASP.2; ICAR research complex, Goa). A value of $P<0.05$ was considered to be statistically significant.

\section{Results and Discussion}

The gossypol detoxifying microorganisms were isolated from cotton rhizosphere and midgut of PBW larvae on minimal media containing 100 ppm gossypol. Nearly 50 isolates were isolated by using gossypol (100ppm) as sole source of carbon on minimal media. When the concentration of gossypol was increased to $250 \mathrm{ppm}$, only a few isolates were able to use and grow on minimal media (Fig. 1 and Table 1). At $500 \mathrm{ppm}$ concentration of gossypol, seven isolates could use gossypol and survive. In a similar study conducted by Yang et al., (2011) gossypol was used as sole carbon source for screening gossypol utilising microbial isolates. As the concentration of gossypol in the minimal media increased the number of isolates able to survive at higher concentration decreased and only a few fungal and actinobacteria isolates were able to survive, this clearly indicates that the gossypol is toxic to majority of the microbial isolates (Margalith, 1967 and Yildirim-Aksoy et al., 2004). The sequence analysis of seven efficient isolates (fungal isolates CICR1to 4 and actinobacterial isolates CICR 5 to 7) was done based on ITS and16S rDNA gene sequencing respectively. The nucleotide sequences of seven isolates were submitted in the NCBI database and details of which are presented in Table 2. The fungal isolates, CICR1 to CICR4, were identified as Aspergillus quadrilineatus (MW228076), A. terreus (MW228075), A. versicolor (MW228100) and Penicillium griseofulvum (MW250237) while actinobacterial isolates CICR5 to CICR7 were identified as Streptomyces maritimus (MW237667), Streptomyces sp. (MW237666) and S. rochei (MW237668). These isolates were further selected for gossypol detoxification studies. The present study reveals that the cotton rhizospheric Aspergillus sp., Penicillium sp. and Streptomyces sp. are predominantly efficient in gossypol degradation. However, 
fungal isolates were more efficient candidate for gossypol detoxification, as they are known to ferment and enrich cotton seed meal (Zhang et al., 2006, Yang et al., 2011, Mageshwaran, 2016 and Mageshwaran et al., 2017) as compared to slow growing actinobacteria. In similar studies, Mageshwaran et al., (2017) identified Aspergillus sp, Lichithemia sp, Alternaria sp and Fusarium sp as a predominant cotton rhizospheric gossypol degrading microorganisms (Fig. 2).

Table.1 Gossypol degrading isolates at different concentration of gossypol on minimal media

\begin{tabular}{|l|l|c|c|c|}
\hline \multirow{2}{*}{ Source } & Microbial & \multicolumn{3}{|c|}{ No. of gossypol degrading isolates } \\
\cline { 2 - 5 } & group & $100 \mathrm{ppm}$ & $250 \mathrm{ppm}$ & $500 \mathrm{ppm}$ \\
\hline \multirow{3}{*}{ Soil } & Fungi & 13 & 10 & 04 \\
\cline { 2 - 5 } & Bacteria & 23 & 10 & nil \\
\cline { 2 - 5 } & Actinobacteria & 10 & 10 & 03 \\
\hline \multirow{3}{*}{ Pink bollworm } & Fungi & 3 & nil & nil \\
\cline { 2 - 5 } & Bacteria & 2 & nil & nil \\
\cline { 2 - 5 } & Actinobacteria & nil & nil & nil \\
\hline
\end{tabular}

Table.2 Details of isolates identified for gossypol detoxification studies on CSM

\begin{tabular}{|l|l|l|l|}
\hline Isolate no. & Source & NCBI Accession number & Identified species \\
\hline CICR1 & Cotton rhizosphere & MW228076 & A. quadrilineatus \\
\hline CICR2 & Cotton rhizosphere & MW228075 & A. terreus \\
\hline CICR3 & Cotton rhizosphere & MW228100 & A. versicolor \\
\hline CICR4 & Cotton rhizosphere & MW250237 & P. griseofulvum \\
\hline CICR5 & Cotton rhizosphere & MW237667 & S. maritimus \\
\hline CICR6 & Cotton rhizosphere & MW237666 & Streptomyces sp. \\
\hline CICR7 & Cotton rhizosphere & MW237668 & S. rochei \\
\hline
\end{tabular}

Table.3 Gossypol degradation efficiency of selected isolates on CSM

\begin{tabular}{|l|c|c|c|c|}
\hline \multicolumn{1}{|c|}{ Treatments } & \multicolumn{2}{|c|}{ Free Gossypol } & \multicolumn{2}{c|}{ Bound gossypol } \\
\cline { 2 - 5 } & FG (\%) & Detoxification (\%) & BG (\%) & Detoxification (\%) \\
\hline A. quadrilineatus CICR- & $0.26^{\mathrm{b}}$ & 16 & $0.46^{\mathrm{c}}$ & 57 \\
\hline A. terreus CICR-2 & $0.20^{\mathrm{c}}$ & 35 & $0.69^{\mathrm{b}}$ & 35 \\
\hline A. versicolor CICR-3 & $0.22^{\mathrm{c}}$ & 29 & $0.61^{\mathrm{b}}$ & 43 \\
\hline P. griseofulvum CICR-4 & $0.10^{\mathrm{d}}$ & 68 & $0.66^{\mathrm{b}}$ & 37 \\
\hline Uninoculated & $0.31^{\mathrm{a}}$ & 0 & $1.06^{\mathrm{a}}$ & 0 \\
\hline CD $(\mathbf{P = 0 . 0 5 )}$ & 0.006 & & 0.012 & \\
\hline
\end{tabular}

Note: Treatment values followed by same letter do not differ significantly at $\mathrm{p}=0.05$ 
Table.4 Qualitative screening for laccase enzyme production and dye decolourisation by gossypol detoxifying isolates

\begin{tabular}{|l|c|c|c|}
\hline Isolates & Guaicol assay & BPB assay & $\begin{array}{c}\text { BPB decolourisation } \\
\text { percent }\end{array}$ \\
\hline $\begin{array}{l}\text { A. } \text { quadrilineatus } \\
\text { CICR-1 }\end{array}$ & ++ & +++ & 82 \\
\hline A. terreus CICR-2 & + & + & 32 \\
\hline A. versicolor CICR-3 & ++ & ++ & 75 \\
\hline P. griseofulvum CICR- & ++ & +++ & 86 \\
\hline
\end{tabular}

Note: +++: Very good, ++: Good, +:Faint

Fig.1 Gossypol degrading isolates at different concentrations of gossypol on minimal media
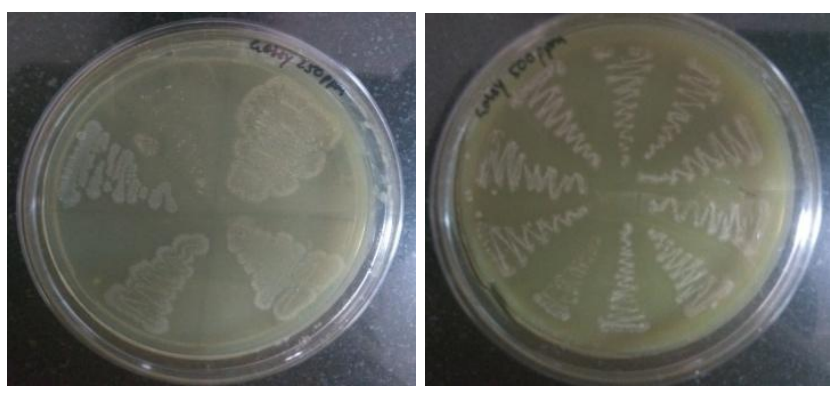

Fig.2 Fungal isolates showing A. Brown (Guaicol assay) and B. Yellow (bromophenol blue assay) discoloration due to laccase activity
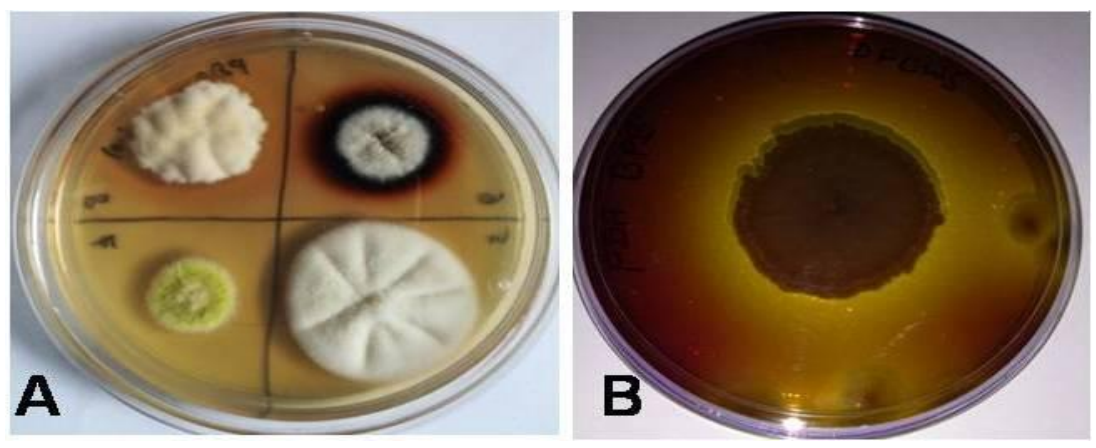

Reduction in the free and bound gossypol in the microbial inoculated CSM as compared to control treatments indicates the efficiency of microbial isolates in gossypol detoxification. The free gossypol level in different treatments ranged between $0.10 \%$ to $0.26 \%$, while, bound gossypol estimated ranged from 0.46 $\%$ to $0.69 \%$. The highest detoxification of free gossypol was observed with $P$. griseofulvum CICR-4 (68\%), which is comparable with
Fusarium thapsinum F-8 (65.2\%) reported by Mageshwaran et al., (2017). Higher bound gossypol detoxification was observed with $A$. quadrilineatus (57\%). The gossypol detoxification efficiency of $S$. maritimus, Streptomyces sp. and S. rochei on CSM were found to be insignificant. Whereas, uninoculated CSM recorded highest free $(0.31$ $\%)$ and bound gossypol levels (1.06 \%) (Table 3). In similar studies by Mageshwaran 
et al., (2017) recorded free gossypol of 0.08 to $0.16 \%$ and total gossypol of 0.94 to $1.30 \%$ in cotton seed cake treated with different cotton rhizospheric gossypol degrading isolates. This clearly indicates gossypol degradation ability of microbial isolates varies among different genera and species and mixed fungal cultures Pleurotus sajor-caju + Saccharomyces cerevisiae and Candida tropicalis $+S$. cerevisiae were efficient in gossypol reduction than single culture on minimal media with gossypol (Mageshwaran et al., 2018). The free gossypol reduction in CSM have been reported for Candida tropicalis, C. capsuligena, Saccharomyces cerevisiae, Aspergillus terricola, A. niger and A. oryzae, Alternaria sp, Fuasrium sp, Pleurotus Sp. (Zhang et al., 2007, Mageshwaran et al., 2017 and Mageshwaran et al., 2018). Nevertheless this study is first of its kind to report soil isolates $P$. griseofulvum, $S$. maritimus, Streptomyces sp. and S. rochei as gossypol utilizing isolates from cotton. $P$. griseofulvum CICR-4 is reported to reduce free gossypol more efficiently on CSM.

The previous studies indicated that the involvement of laccase in degradation of gossypol however the detailed mechanism of gossypol degradation by fungal strains is yet to be studied in detail. The up-regulation of laccase and some unknown proteins in $A$. niger and their possible involvement in gossypol detoxification has been reported (Yang et al., 2012). Similarly, Mageshwaran et al., (2018) reported the involvement of laccase enzyme with the molecular weight ranged from 45 to $66 \mathrm{kDa}$ in biotransformation of gossypol. Dye decolourisation by selected isolates on potato dextrose broth with BPB indicates around 32 to $86 \%$ decolourisation after $72 \mathrm{~h}$ of incubation. The maximum BPB decolourisation (86\%) was observed in the culture supernatant of $P$. griseofulvum CICR4. Decolourisation is directly correlated with color intensity observed on PDA plates around colonies. The percent dye decolourisation can be correlated with the laccase activity levels (Rodriguez et al., 1999) (Table 4).

In conclusion, following fungi ( $A$. quadrilineatus, A. terreus, A. versicolor, $P$. griseofulvum) and actinobacteria (Streptomyces maritimus, Streptomyces $s p$, Streptomyces rochei), were identified as gossypol utilising microorganisms from cotton rhizophere. Among the above mentioned microorganisms, P. griseofulvum, S. maritimus, Streptomyces sp and S. rochei were reported to be novel gossypol utilising strains from cotton soil. However, actinobacteria were not found to be as efficient as fungal isolates in reduction of free and bound gossypol.The short-listed strains produce laccase enzyme which is known to be involved in degradation of gossypol. The identified strains would add to the list of efficient microbial strains identified for gossypol detoxification for utilisation in solid state fermentation.

\section{Acknowledgement}

The authors are thankful to Indian Council of Agricultural Research, New Delhi and Director, ICAR-CICR, Nagpur for providing the financial assistance to carry out this experiment.

\section{References}

Alexander, J., Benford, D., Cockburn, A. et al., 2008. Gossypol as undesirable substance in animal feed. The EFSA Journal, 908: 1-55.

Altschul, S. F., Gish, W., Miller, W., Myers, E. W. and Lipman, D. J. 1990. Basic local alignment search tool. Journal of Molecular Biology, 215: 403-410.

AOCS. 1989. Free and total gossypol 
methods. Official and tentative methods of the AOCS, $4^{\text {th }}$ edn. American oil chemists society, Chicago, pp 1-5.

Arieli, A. 1998. Whole cottonseed in dairy cattle feeding: a review. Animal Feed Science and Technology, 72: 97-110.

Blevins, S., Siegel, P. B., Blodgett, D. J., Ehrich, M., Saunders, G. K. and Lewis, R. M. 2010. Effects of silymarin on gossypol toxicosis in divergent lines of chickens. Poultry Science, 89:18781886.

Braga, A. P., Maciel, M. V., Guerra, D. G. F., Maia, I. S. A. S., Oloris, S. C. S. and Soto-blanco, B. 2012. Extruded-expelled cottonseed meal decreases lymphocyte counts in male sheep. Revue de Medecine Veterinaire, 163: 147-152.

Brock, T.D., Madigan, M.T., Martinko, J. M. and Parker, J. 1994. Biology of Microorganisms. Prentice-Hall, Englewood cliffs, NJ.

El-Mokadem, M. Y., Taha, T. A., Samak, M. A. and Yassen, A. M. 2012. Alleviation of reproductive toxicity of gossypol using selenium supplementation in rams. Journal of Animal Science, 90: 32743285.

Gadelha, I. C. N., Fonseca, N. B. S., Oloris, S. C. S., Melo, M. M. and Blanco, B. S. 2014. Gossypol toxicity from cottonseed products. The Science World Journal, $1: 1-11$

Jianyi, S. 1997. Study on properties of a Candida tropicalis new strain for solid substrate fermentation and its application. Journal of Zhejiang Agriculture University, 18: 81-5

Kalra, K., Chauhan, R., Shavez, M. and Sachdeva, S. 2013. Isolation of laccase producing Trichoderma sp. and effect of $\mathrm{pH}$ and temperature on its activity. International Journal of ChemTech Research, 5: 2229-2235.

Khalaf, M. A. and Meleigy, S. A. 2008. Reduction of free gossypol levels in cottonseed meal by microbial treatment. International Journal of Agriculture and Biology, 10:185-190.

Lin, Y. C., Fukaya, T., Rikihisa, Y. and Walton, A. 1985. Gossypol in female fertility control: ovum implantation and early pregnancy inhibited in rats. Life Sciences, 37: 39-47.

Mageshwaran, V and Parvez, N. 2016. Gossypol detoxification and lysine enrichment in cottonseed cake by solid state fermentation, Journal of Pure and Applied Microbiology, 10: 1333-1339.

Mageshwaran, V., Sharma, V., Chinnkar, M., Parvez, N. and Krishnan, V. 2018. Biodegradation of gossypol by mixed fungal cultures in minimal medium. Applied Biochemistry and Microbiology, 54: 301-308.

Mageshwaran, V., Sharmila B. M. and Kuppusamy, P. 2017. Isolation and identification of potential gossypol degrading fungal strains from cotton growing soil. Microbiology Research Journal International. 21(1): 1-6.

Margalith, P. 1967. Inhibitory effect of gossypol on microorganisms. Applied Microbiology, 15: 952-953

Nagalakshmi, D., Sastry, V. R. B. and Agrawal, D. K. 2002. Detoxification of undecorticated cottonseed meal by various physical and chemical methods. Animal Nutrition and Feed Technology, 2:117-126.

Noftsger, S. M., Hopkins, B. A., Diaz, D. E., Brownie, C. and Whitlow, L. W. 2000. Effect of whole and expanded-expelled cottonseed on milk yield and blood gossypol. Journal of Dairy Science, 83: 2539-2547.

Panigrahi, S. and Plumb, V. E. 1996. Effects on dietary phosphorus of treating cottonseed meal with crystalline ferrous sulphate for the prevention of brown yolk discolouration. British Poultry Science, 37:403-411. 
Rajesh Kumar, Jaswinder Kaur, Saurabh Jain and Ashwani Kumar. 2016. Optimization of laccase production from Aspergillus flavus by design of experiment technique: Partial purification and characterization. Journal of Genetic Engineering and Biotechnology, 14: 125-131.

Randel, R. D., Chase, C. C. Jr., and Wyse, S. J. 1992. Effects of gossypol and cottonseed products on reproduction of mammals. Journal of Animal Science, 70:1628-1638.

Regode, V., Kuruba, S., Mohammad, A. S. and Sharma, H. C. 2016. Isolation and characterization of gut bacterial proteases involved in inducing pathogenicity of Bacillus thuringiensis toxin in cotton bollworm, Helicoverpa armigera. Frontiers in Microbiology, 7:1567.

Rodriguez, E., Pickard, M.A. and VazquezDuhalt, R. 1999. Industrial dye decolorization by lacases from ligninolytic fungi. Current Microbiology, 38: 27-32.

Saki, A. A., Poumia, K., Tabatabaie, M. M., Zamani, P., Haghighat, M. and Salary, J. 2012. Effects of cottonseed meal supplemented with lysine and enzyme (Hydroenzyme XP) on egg quality and performance of laying hens. Revista Brasileira de Zootecnia, 41: 2225-2231.

Sein, G. M. 1986. The embryotoxic and immunodepressive effects of gossypol. American Journal of Chinese Medicine, 14: 110-115.

Shawrang, P., Mansouri, M. H., Sadeghi, A. A. and Ziaie, F. 2011. Evaluation and comparison of gamma- and electron beam irradiation effects on total and free gossypol of cottonseed meal. Radiation Physics and Chemistry, 80:761-762.

Shi, A. H., Zhang, Y., Qu, P., Yan, J. G. and Xiao, H. J. 1998. Screening and breeding of highly-effected degrading cotton-phenol strains and study on detoxification technology and conditions. Acta Microbiologica Sinica, 38: 318-20.

Sun, Z. T., Liu, C. and Du, J. H. 2008. Optimisation of fermentation medium for the detoxification of free gossypol in cottonseed powder by Geotrichum candidum G07 in solid-state fermentation with response surface methodology. Annals of Microbiology, 58: 683-690.

Tekere, M., Mswakab, A.Y., Zvauyaa, R., Reada, J. S. 2001. Growth, dye degradation and ligninolytic activity studies on Zimbabwean white rot fungi. Enzyme and Microbial Technology, 28:420-426.

Tian, X., Ruan, J., Huang, J., Fang, X., Mao, Y., Wang, L., Chen, X. and Yang, C. 2016. Gossypol: phytoalexin of cotton. Science China Life Sciences, 59: 122129.

Velasquez-pereira, J., Chenoweth, P. J., Mcdowell, L. R., Risco, C. A., Staples, C. A. and Prichard, D. 1998. Reproductive effects of feeding gossypol and vitamin $\mathrm{E}$ to bulls. Journal of Animal Science, 76: 2894-2904.

Weisburg, W. G., Barns, S. M., Pelletier, D. A. and Lane, D. J. 1990. 16S ribosomal DNA amplification for phylogenetic study. Journal of Bacteriology, 173: 697-703.

Weng, X. Y. and Sun J.Y. 2006. Biodegradation of free gossypol by a new strain of Candida tropicalis under solid-state fermentation: effects of fermentation parameters. Process Biochemistry, 41: 1663-1668.

White, T. J., Bruns, T., Lee, S. and Taylor, J. 1990. Amplification and direct sequencing of fungal ribosomal RNA genes for phylogenetics. In: Innis, M.A., Gelfand, D.H., Sninsky, J.J. (Eds.), PCR Protocols: A Guide to Methods and 
Applications. Academic Press, New York, pp. 315-322.

Wu, X. Y. and Chen, J. X. 1989. The utilization of microbes to break down FG in cottonseed meal. Sci. Agric. Sin., 22: $82-6$

$\mathrm{Xu}, \quad$ W-B., $\mathrm{Xu}, \quad$ L-H., Lu, H-S., OuYang., Dong-yun., Shi, H-J., Di, J-F and He, X-H. 2009. The immunosuppressive effect of gossypol in mice is mediated by inhibition of lymphocyte proliferation and by induction of cell apoptosis, Acta Pharmacologica Sinica, 30: 597-604.

Yang, X., Guo, J. and Sun, J. 2011. Biodegradation of free-gossypol by a new fungus isolated from cotton planted soil. African Journal of Microbiology Research, 5:3066-3072.

Yang, X., Sun, J-Y., Guob, J-L. and Weng, X. Y., 2012. Identification and proteomic analysis of a novel gossypol-degrading fungal strain. Journal of the Science of
Food and Agriculture, 92: 943-951

Yildirim-Aksoy, M., Lim, C., Dowd, M. K., Wan, P. J., Klesius, P. H. and Shoemaker, C. 2004. In vitro inhibitory effect of gossypol from gossypol-acetic acid, and (+)- and (-)-isomers of gossypol on the growth of Edwardsiella ictaluri.Journal of Applied Microbiology, 97: 87-92.

Zhang, W., Xu, Z., Sun, J. and Yang, X. 2006. A study on the reduction of gossypol levels by mixed culture solid substrate fermentation of cottonseed meal. Asian -Australian Journal of Animal Sciences, 19: 1314-1321.

Zhang,W-J., Xu, Z-R., Zhao, S-H., Sun, J-Y and Yang, X. 2007. Development of a microbial fermentation process for detoxification of gossypol in cottonseed meal. Animal Feed Science and Technology, 135: 176-186.

\section{How to cite this article:}

Savitha Santosh, K.P. Raghavendra, K. Velmourougane, V. Mageshwaran, D. Blaise and Waghmare, V.N. 2020. Microbial Detoxification of Gossypol in Cotton Seed Meal by Solid Substrate Fermentation. Int.J.Curr.Microbiol.App.Sci. 9(12): 1654-1663. doi: https://doi.org/10.20546/ijcmas.2020.912.197 